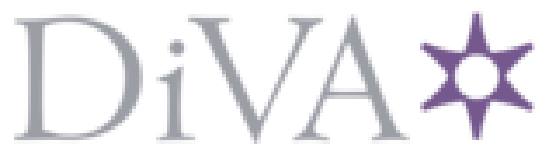

http://www.diva-portal.org

This is the published version of a paper published in .

Citation for the original published paper (version of record):

Rosén, M., Arneback, E. (2021)

Living the Paradox of Risk: An Approach for Teachers in Democratically Challenging

Situations in Education

Philosophical Inquiry in Education, 28(1): 1-11

Access to the published version may require subscription.

N.B. When citing this work, cite the original published paper.

Permanent link to this version:

http://urn.kb.se/resolve?urn=urn:nbn:se:oru:diva-92869 


\title{
Living the Paradox of Risk: An Approach for Teachers in Democratically Challenging Situations in Education
}

\author{
MARIA ROSÉN \\ Uppsala University, Sweden \\ EMMA ARNEBACK \\ Örebro University, Sweden
}

\begin{abstract}
This essay elaborates on the notion of risk in relation to democratically challenging situations in education. This refers to situations in which liberal democratic values are potentially challenged, such as in teaching about controversial issues and in moments of expressions of burtful speech, which can create in teachers an ambivalence for how to act. The essay takes an understanding of risk as holding a plurality, viewing risk as both undesirable and desirable, to be both reduced and embraced. By considering perspectives that implicitly relate to risk in various ways, this essay explores what can be made possible by embracing risk or its reduction in democratically challenging situations. These perspectives envisage tension between different approaches to risk and visualize how risk may be viewed both as possible moments of change and as possible moments of violence. The essay advances the argument that a one-sided approach to risk may thus pose a challenge to the struggle for democracy, arguing instead for a complex approach to risk. Making use of Jonna Bornemark's work on the "paradox of action," the essay proposes the viewing of risk as a paradox, spanning our world of action. The paradox formulates a mutual dependence, in which more is required of one side in one moment and more of the other in the next; neither can be neglected. The essay proposes an approach for teachers: "living the paradox of risk," which is to act in the space between reducing risk. and embracing risk. in democratically challenging situations.
\end{abstract}

\section{Introduction}

In this essay, we elaborate on the notion of risk in relation to democratically challenging classroom situations. This means that we are concerned with situations in education in which liberal democratic values are potentially challenged (cf. Franck, 2020), moments that often lead to an ambivalence among teachers on how to act. These moments can, for example, occur when issues concerning culture, racism, religion, sexuality, or gender are addressed in education; when controversial issues are discussed; or when expressions of hurtful speech are made in the classroom. Such moments activate discussions on how to engage in values in a democratic society. For example, is it more democratic to secure freedom of speech in education or to ensure that no one suffers from hurtful speech? Is it democratic to give room for discussion on loaded topics, such as the occurrence of racism and sexism 
in society, or does it rather lead to reproducing oppressive power relations? In this essay we highlight the need to maintain these kinds of tensions. With this it follows that we understand liberal democratic values not as ideals to be achieved, but as non-linear qualities to engage in and struggle for, through a responsiveness to processes in the here and now.

By putting the notion of risk at the centre of this struggle we explore how different perspectives explicitly or implicitly relate to risk in their responses to democratically challenging situations. A point of departure for this exploration is an understanding of risk as a concept that holds a dual meaning as both undesirable and desirable. As a concept, risk has no agreed upon definition, whether in ordinary usage or in science. Rather it is a concept with multiple definitions (Aven, 2012. See also Renn, 1992). According to Aven, "Some definitions are based on probability, chance or expected values, some on undesirable events or danger, and others on uncertainties" (2012, p. 33). Although its origin is inconclusive and disputed (Oxford English Dictionary, 2021; cf. Aven, 2012), plurality seems in line with the etymology of the word "risk." According to the Oxford English Dictionary (2021), it is suggested that the post-classical Latin resicum, risicum, etc., in the sense of "danger, hazard," ultimately derives from the classical Latin resecare, meaning "that which cuts," and hence "rock, crag, reef," alluding to the hazards of travel or transport by sea. Conversely, it has also been argued that the post-classical Latin resicum, risicum, etc., derive from the Arabic rizq, in the specific senses of "fortune, luck, destiny, chance." This illustrates both the enabling and limiting connotations of risk.

As a societal phenomenon, risk has been discussed in terms of "risk consciousness," which emerged in Western culture in the 1960s (Beck, 1992), and of risk management through, for example, laws and policies (cf. Alvesson, 2019; Bialostok \& Whitman, 2012). This also holds true for education, which has moved towards predictability and managing risks (cf. Bialostok \& Whitman, 2012; Biesta, 2014, 2016; Murphy, 2020). One example comes from Sweden, which in the last 15 to 20 years has seen a radical shift in the use of law in the governing of education, featuring increasingly detailed legal regulations, strong accountability measures, and a growing bureaucracy at all levels in the education system (Rosén, Arneback, and Bergh, 2020; Novak, 2018; cf. Murphy, 2020). The legislation has, among other things, partly changed the broader democratic mission of education, with a move towards identifying, analyzing, and removing risks of violence, discrimination, harassment, and other harms to students' dignity (Arneback, 2012; Cooper, 2019). As a response to the general push towards making education predictable and a risk-free space, Gert Biesta (2014) argues instead for a pedagogy that takes "the beautiful risk of education." Biesta here points to risk as a condition of education, one that enable its function of subjectification. Without going into Biesta's theory on risk, this call to embrace risk - and the possibilities it opens for allowing something new emerge - has inspired us to think further about risk in education.

As this essay will illustrate, while varying perspectives envisage tensions between different approaches to risk, risk may also be viewed both as a possible moment of change and one of possible violence. ${ }^{1}$ Thus, in the philosophical research on democratically challenging situations in education, we find perspectives that, implicitly, relate to risk in different ways. On the one hand, we find perspectives that relate to reducing risk: embracing certainty, predictability, and closeness (e.g., Applebaum, 2003; Hübinette, 2012). On the other hand, we find perspectives that relate to embracing risk: embracing uncertainty, unpredictability, and openness (e.g., Boler, 2004; Ruitenberg, 2017; Todd, 2010; Zembylas, 2015). In our exploration we engage with different perspectives with the following question: What can an embrace of risk or its reduction make possible in relation to democratically challenging situations? We elaborate on, and successively construct, these two approaches to risk, that is, reducing risk and embracing risk. In the final section we propose viewing these approaches as two

\footnotetext{
1 Violence is used as a broad concept in the essay. Given that the references we draw on speak of violence in slightly different ways (in terms of, for example, harassment, hate speech, hurtful discourses, and antagonism), we are in this essay sensitive to the pluralism of ways of conceptualizing and relating to violence.
} 
sides of a paradox: a paradox of risk, spanning our world of action. Instead of trying to resolve the paradoxical tension of risk, we argue that teachers need to stay and act within this tension, which we term "living the paradox of risk." Through this theoretical argument, we bring conflictual perspectives together and argue for a complex approach to risk in democratically challenging situations in education. Besides this theoretical contribution, we lay the ground for reflection on some of the everyday democratic struggles in education.

\section{Reducing Risk in Democratically Challenging Situations}

Democratically challenging situations raise several issues of relevance to education. One central issue concerns the space available for controversial issues. Research focusing on reducing risk in the name of democracy often highlights the importance of communication on controversial issues, but also the need to delineate the borders of democratic communication. With this follows questions such as what the risk could be in democratically challenging situations, for whom there is risk, and how risk should be reduced. In this section, we consider research from the field of philosophy of education, to illustrate how the question of reducing risk can be understood as crucial. In addition, we consider the case of Swedish education policy, mentioned in the introduction, for which we turn to curriculum theory and education law and policy.

When it comes to the question of what is at risk, there are several values held to be universal that provide answers in this regard, such as principles of human rights, democracy, and nondiscrimination. Universalistic approaches are fairly easy to incorporate into policy documents, for example, to establish a value base for education and boundaries for freedom of speech. Swedish policy and law provide an example of this way of addressing risk. Since 2006 there is a strict legal ban on discrimination and other kinds of violence ${ }^{2}$ related to sex, transgender identity or expression, ethnicity, religion or other belief, disability, sexual orientation, and age (SFS 2008:567; SFS 2010:800). Under this law, educational staff are obliged to investigate but also report all suspected incidents to the principal, who in turn must take it to the school's governing body. Furthermore, educational staff must regularly identify and remove risks of violence (Swedish National Agency for Education, 2012). Altogether the task for educational staff is to secure a safe environment for children and students by reducing risk (Government Bill 2005/06:38) and by making education predictable.

This way of formulating this mission of education - as risk reduction - has implications for the framing of democracy and education (Bergh \& Arneback 2016; Cooper, 2019). A broader tendency is for issues that were once framed as the ethical responsibility of teachers to now be framed as legal obligations (Bergh \& Arneback, 2016; Hult \& Lindgren, 2016; Lindgren, et al., 2018; Runesdotter, 2016). For teachers, this new framing also has implications for how they are supposed to act in democratically challenging situations. Earlier research has shown that this legal non-violation principle has become a benchmark for when school staff need to act, leading to a focus on reducing the risk of potentially hurtful communication (Arneback, 2012; cf. Carlbaum, 2017; Martinsson \& Reimers, 2014). This means, for instance, that teachers have a responsibility to limit students from expressing political views in the classroom that could risk hurting other students, in order to establish a "riskfree" environment.

In the philosophy of education, this way of addressing risk is expressed in similar but different terms. One way to argue for reducing risks in education is, following Eamonn Callan $(2011 ; 2016)$, to highlight the importance of virtues. Teachers, he argues, need to create spaces in education that are safe for dignity but that are intellectually unsafe, by focusing on dignity and civility. He writes, "There

2 The Swedish legislation covers a variety of acts, spanning acts of discrimination and different forms of harassment, including speech and acts of threat or physical violence, which harm students' "dignity." 
is an important area of convergence between cultivating open-mindedness in a context of disagreement and fostering the civility that would secure dignity safety for all" (Callan, 2016, p. 75).

Another way to address the question of reducing risk is, as Barbara Applebaum (2003; see also Hübinette, 2012) argues, to leave no room for "words that wound" and that mirror unjust social relations. What is highlighted as the risk here is the reproduction of oppression, which must be taken seriously. Thus, communication that poses this risk must be reduced, and teachers' authority should be used to interrupt dominant structures of power. To illustrate this argument, Appelbaum gives the example of a situation in which a student who practices Christianity talks negatively about homosexuality in one of her classes, while another student admits, in private, "that he does not feel safe disclosing to the rest of the predominantly white, Christian students in our class that he is gay" (Applebaum, 2003, p. 152). This line of argumentation makes it possible to raise the question of who is at risk. Such kinds of democratically challenging situations, Appelbaum argues, can put an impossible pressure on students from marginalized groups. To reduce the risk of oppression, teachers therefore need to take responsibility for balancing power in the classroom by limiting dominant voices and foregrounding marginalized voices.

Such a situation illustrates the exposure for students that can follow with allowing hurtful speech in educational contexts, since "speech that supports and is supported by dominant ideology becomes, at the moment of its utterance, the reproduction of power" (ibid., p. 157). Basing her arguments on J.L. Austin's work on speech acts, Applebaum emphasizes that some speech acts are in themselves violent in the way they position people: "Racist speech, therefore, has illocutionary force because it racializes people; it discursively brings certain types of identities into being" (ibid., p. 156). This is thus the risk when certain forms of speech are used, and which motivates the narrowing of the space in which discussions can be had. For a teacher, Applebaum argues, this means that students who express views that reproduce structural oppression in society should not be allowed to deliberate freely upon these topics in the classroom. The benefit of creating a safer school environment for marginalized groups is worth the cost of silencing students in positions of power.

To reduce the risk of oppression in school, Appelbaum argues for the application of universal principles to the limits of speech in educational contexts. She argues that "the liberal belief in freedom of expression and a market-place of ideas is compelling only if all viewpoints have an equal opportunity to have their voices matter" (ibid., p. 159). However, to avoid creating a situation in which power becomes hidden in the process of affirmative actions, Applebaum suggests that such discussions may be held with students outside the classroom:

Until I am convinced that my classroom can become a safe zone for everyone, I will simply invite my religious student to my office, where I will be glad to discuss her concerns more extensively. (Ibid., p. 161)

By considering Applebaum's philosophical approach to "words that wound," as well as Callan's emphasis on "dignity safe," and education policy and law in Sweden, this section has illustrated the idea of reducing risks in democratically challenging situations. If anyone is (at risk of being) violated, oppressed, or humiliated in the classroom - by the teaching content or by another person - the space for communication in the classroom must be narrowed, and if necessary, taken elsewhere. The interrelated answers to the questions what is at risk, who is at risk, and how can risk be reduced, shed light on the overall question of the possibilities of reducing risk in relation to democratically challenging situations in the everyday classroom.

As illustrated above, attempts to reduce risk may prevent violent moments of oppression and injustice in the classroom, and remind us to bear in mind the possible consequences of reproducing power in educational contexts, and how it can affect individual students. However, taking this approach to risk may also mean missing out on transformative moments and processes in education that could enable change (Arneback, 2012. See also Carlbaum, 2017). Thus, trying to reduce risk is not 
exclusively a constructive endeavour, and in fact may make certain education processes impossible. Moreover, a safe and risk-free environment might not even be possible to achieve (cf. Boler \& Zembylas, 2003; Mouffe, 2005; Zembylas, 2015). Accordingly, we need to reflect on why, how, and when there is motivation to reduce risk in education.

\section{Embracing Risk in Democratically Challenging Situations}

In this section we consider theoretical contributions in the philosophy of education to illustrate how the question of embracing risk can be understood as crucial. Embracing risk should not, however, be understood as permitting violence, but rather that democratically challenging situations need to be responded to differently - by embracing risk, unpredictability, uncertainty, and openness. In this view, risk is, in a sense, desirable. As will be illustrated, these perspectives often highlight plurality and transformative moments in education. With this follows questions as to what a risk is, what risk can make possible, for whom risk is a possibility, and how risk can be embraced. When it comes to the question of what risk can make possible, these perspectives explicitly value the political and public dimensions of education. As a consequence, hurtful discourses and cultural conflicts discussed here are not seen as individual and moral affairs to be handled in private, but rather as collective affairs to be handled in public as political matters.

An illustrative example of the possibilities of embracing risk in democratically challenging situations is found in the work of Sharon Todd (2010. See also Todd \& Säfström, 2008). Building on the radical democratic theories of Chantal Mouffe and Jacques Rancière, Todd adopts an agonistic approach to conflicts in educational settings, which rests on the assumption that social life always contains a conflictual dimension (cf. Mouffe, 2005). In particular, Todd engages with culture conflicts characterized by racism, nationalist and anti-religious sentiments, their appearance in the present, and how these can be met face to face.

Todd argues that conflicts force teachers to reflect upon how they can be met, and suggests reflecting upon the political dimension of culture conflicts. This is important, as culture conflicts in education often mirror political conflicts in society. In contrast to the perspectives discussed in the previous section, this also means that instead of silencing uncomfortable views and voices, we should concentrate on the challenges of living in a plural society, which is often characterized by unequal conditions. We thus understand this argument as critical of closing the space in education for discussions on controversial issues.

So what could it mean, to meet conflicts face to face? Here, Todd suggests two kinds of actions, both of which embrace risk. The first is to repoliticize conflicts, which implies moving away from an understanding of conflicts as moral deficits, as this hinders equality. Todd warns:

In fact, not allowing conflicting positions for moral reasons - or resolving conflicts by sweeping them under the rug - jeopardizes equality's opportunity to assert itself when it conflicts with school traditions. (2010, p. 190)

The second action is to give students an opportunity to develop the political space. The question of risk for whom is thus addressed in a broader sense: as a possibility for all students. This can be done by introducing students to a political language (cf. Ruitenberg, 2008; 2010), which gives them an opportunity to see and understand how their own emotions and attitudes give rise to political, not just moral, exclusions. In line with this, Todd argues that it is important to help students to "transform antagonistic conflicts, where exclusion risks leading to violence, into agonistic conflicts" (Todd, 2010, p. 190). This implies redefining the kinds of conflicts that are manifested in an us-versus-them relationship, "relationships that are constantly changing and temporary - and helping them to 
understand emotions without being able to live in the fragile and unstable rooms characterized by 'conflicting consensus"' (ibid., p. 190).

Such processes of transformation imply an embracing of risk in the sense that they open up the communicative space, characterized by uncertainty and unpredictability. By engaging in conflicts politicizing them, and giving room for political subjectivity - more violent antagonistic conflicts in the school setting and in society may be prevented. Some kind of risk, in the sense of uncertainty, may thus be necessary to reduce the risk of violent conflicts.

In relation to the question on how to embrace risk in democratically challenging situations, Ruitenberg (2017) also reminds us of the need to attend to moments of risk and uncertainty. In her work on the discursive responsibility of educators, she, like Appelbaum, sheds light upon "words that wound" in education. However, while Appelbaum discusses how to limit the space for communication that poses risks of hurtful speech and violence toward marginalized groups, Ruitenberg focuses on the student group as a whole, and on using the space in the classroom for educational responses.

Specifically, she engages with the discursive transformation in teachers' responses to hurtful speech in education. This includes all speech acts that can have negative effects on others, such as speech that is perceived as homophobic, sexist, racist, or in other ways insulting or demeaning. Like Applebaum, Ruitenberg builds on J.L. Austin, and is concerned with what words can do. Turning to Foucault, she extends the understanding of language and engages with the hurtful discourses that circulate in educational spaces. She argues that, in the classroom, hurtful language is not a private but a public concern, as our words have effects on people beyond our intentions, and that this is also something students should learn. When educators respond to language, this needs to occur at the same level of publicity, or nearly the same, as all language that circulates in educational spaces is part of what is being taught.

As the expression "the words hung in the air" suggests, words do not disappear after they have been spoken; they linger, leave a trace, hang in the air as they do in the memories of those who heard them, regardless of whether they were the intended audience. (Ruitenberg, 2017, p. 216)

Educators thus have what she calls a "discursive responsibility" to respond educationally to hurtful discourses circulating in educational contexts, whether these emerge from themselves, as educators, or from others. The question of how risk is embraced is here clearly an educational question, and both the students and the discourses become answers to the question of who is at risk, thus addressing the issue at both an individual and a structural level. In arguing for an educational responsibility for responding to hurtful discourses, we find that Ruitenberg illustrates not only the responsibility for, but also the potential of using the classroom for transformation when hurtful speech occurs.

By visiting the theoretical contributions of Todd and Ruitenberg, we have in this section illustrated some of the possibilities of embracing risk in responding to democratically challenging situations. In this approach, school is viewed as a political and public space, and teachers are encouraged to embrace moments of risk and uncertainty in situations when controversial issues are addressed and hurtful speech occurs. The examples highlighted here of what a risk is and how risk can be embraced together open up space to transform hurtful discourses and conflicts, and for taking responsibility for the classroom as an educational space. In this sense, risk becomes a question for all students - answering the question of who is at risk. 


\section{Toward an Approach to Risk in Democratically Challenging Situations: Living the Paradox of Risk}

In the previous sections, we have visited different perspectives and elaborated on their approaches to risk, and explored their possibilities and potentials. On a more general level we see how risk can be viewed as both problematic and desirable. As a teacher, to act in loaded situations, such as when teaching on controversial issues or responding to hurtful speech, is about navigating risk - in a double sense. While reducing risk reminds us of what could be a risk, embracing risk reminds us of the possibility and educational responsibility for transformation. We argue that a one-sided approach - to reduce or embrace alone - poses challenges to struggles for democracy within the classroom. On the one hand, a one-sided focus on eliminating risk may hinder transformation. If the space for controversial issues is narrowed or even closed down, and hateful speech is simply silenced, there is less room in which to discuss these crucial matters in an educational way. On the other hand, a onesided embrace of risk - disregarding the complex ways in which power plays out and affects students differently - may become too violent for certain students. If communication is too painful it may simply (re)produce layers of oppression within the classroom. Against the backdrop of this conclusion, we will, in this final section, argue for a complex approach to risk, which we term "living the paradox of risk." We begin by discussing the "paradox of action," a concept introduced by Jonna Bornemark $(2019 ; 2020)$. We use this concept to provide a theoretical outline of what we mean by living the paradox of risk, followed by an example of a classroom situation.

In line with Bornemark (2019; 2020), we understand "paradox" as a field of tension spanning our world of action (cf. Arneback, 2014; Dewey, 1922). Here paradox should not be understood, as is often done, as an inconsistency that can be repealed by thinking it through and thinking "right." To illustrate this kind of paradox, ${ }^{3}$ Bornemark discusses love as an example:

In love, there is this tension between getting so close that differences dissolve and of keeping the other as other, neither side can disappear. Love may even be this insoluble tension. The paradox is at the same time complex, enjoyable and painful. The difficult situations where judgment is needed occur within such paradoxes. (2020, p. 82, our translation)

Bornemark suggests we should thus rather think of the paradox as formulating a mutual dependence, in which more is required of one side in one moment and more of the other side in the next: neither can be neglected. And without paradoxes, there is no world of action. From this, we can see how risk may be viewed as simultaneously problematic and desirable. To exercise responsibility is thus to consciously relate to the paradox. In every situation the paradox is actualized in slightly different ways, and with every action within the paradox there is the risk that it will not turn out as desired. Yet we can only continue to try to understand, and continuously relate to the paradox, over and over again (Bornemark, 2020).

By thinking of risk and responsibility in this way, "living the paradox of risk" offers an approach for teachers to engage in and struggle for democracy through staying responsive to processes as they occur. The two approaches to risk are reminders of the complexity of the struggle for democracy in education, yet they sometimes create in teachers an ambivalence for how to act. While reducing risk and embracing risk can be separated analytically, in practice both must be taken into consideration. In specific democratically challenging moments, instead of trying to resolve a paradoxical tension, teachers need to stay and act within it. The paradox of risk creates a space for

\footnotetext{
${ }^{3}$ Bornemark further discusses this view of paradoxes, which comes from the mystics, in Kunskapens gräns, gränsens vetande: En fenomenologisk undersökning av transcendens och kroppslighet [The limit of knowledge, the knowledge of limit: A phenomenological study of transcendence and body]. Södertörn Philosophical Studies, no. 6, Huddinge: Södertörn University, 2009, pp. 373, 379.
} 
teachers' actions: to act towards predictability and certainty in one moment and towards unpredictability and uncertainty in another, depending on what needs to be cared for in that particular moment. Thus, in one moment risk is a potential problem to be reduced, and in the next moment it is a potential to be embraced. By remaining aware of the two approaches to risk, and the space to move between them, teachers are reminded to make thoughtful and considered contextual choices about how to approach the paradox in democratically challenging moments.

To further illustrate what it may mean to live the paradox of risk, let us imagine a possible teaching situation in the context of Sweden. With an increased number of asylum seekers entering Sweden from 2015, the political conversation about migration has shifted towards a tougher migration policy, with growing support for the far right Sweden Democrats party. This means that in a classroom there can both be students who express racism more or less explicitly, and those who have recently fled war-torn areas such as Syria.

Given this specific context, imagine a classroom in which the teacher has planned a history lesson on migration and starts by inviting students to give examples of migration. Through the teacher's decision to teach on this loaded topic, the paradox of risk is significant from the start. Very soon the discussion turns from migration in the past to current Swedish migration policy, with some students voicing dehumanizing and racist opinions. The atmosphere becomes heated, and seemingly uncomfortable for many of the students. The teacher is aware that the situation has moved towards an antagonistic conflict, with possible oppressive outcomes. To reduce this risk, she continues to embrace risk in the sense that she keeps the discussion going, but now by attempting to change the direction of the discussion. Specifically, she continues by recognizing the emotions that have arisen and trying to (re)orientate them by turning to the Holocaust - the often-used grand narrative in Sweden for discussing divisions between groups of people and dehumanization in a historical light (cf. Tryggvasson \& Mårdh, 2019). The teacher describes how, step by step, Nazism became a normalized ideology, leading to the National Socialist German Workers' Party coming into power. However, in this classroom discussion, the educational and transformative move becomes increasingly challenging. Suddenly, one of the students calls out: "It's different from the Holocaust. We're not going to kill them, they just need to go home. Sweden belongs to the Swedes." As the teacher addresses the hurtful speech launched in the classroom, affecting all the students, she realizes the situation has reached a point at which the risk of violence and oppression for some students must be reduced immediately. The moment obviously requires her to now approach the paradox in a different way. Quickly, she cuts off the degenerating discussion - for now - and makes a distracting manoeuvre: "This discussion has gone off track and I am going to pull the emergency brake. Let us now turn to the questions you were to reflect on for today."

As this example illustrates, the teacher approaches the paradox over and over again, in a continuous process, staying sensitive to a context that is constantly changing (cf. Arneback, 2014). She recognizes how power plays out in unpredictable and challenging ways, and values different actions in different moments. This is what it means to live the paradox of risk.

Finally, by proposing to live the paradox of risk we have in this essay argued for the value of taking both sides of the paradox into account and have acknowledged that teaching is contextual. This further raises the question of which societal conditions, as they appear in educational policy, enable or challenge us to live the paradox of risk in democratically challenging situations in education. In the light of the strong tendency towards predictability and risk reduction, we argue that theoretical perspectives that nurture a counter-discourse are of specific importance, and remind us of the democratic and educational qualities that are at play. 


\section{Acknowledgments}

We would like to thank the research groups Education and Democracy at Örebro University and Studies in Educational Policy and Educational Philosophy at Uppsala University, as well as Andreas Bergh, Jonna Bornemark, and Elisabeth Langmann for their thought-provoking comments and discussions on earlier drafts. We are grateful for the valuable editorial suggestions by David Waddington and the comments of the anonymous reviewers. An early version of this paper was scheduled to be presented at the AERA 2020 Annual Meeting (SIG-Philosophical Studies in Education), but was cancelled due to the pandemic. Emma Arneback's part in the work was supported by funds from the Swedish Research Council for the project How to Counteract Racism in Education [grant number 2015-01046].

\section{References}

Alvesson, M. (2019). Extra allt!: När sambälls- och människoförbättrandet slär tillbaka [Extra all!: When the improvement of society and people strikes back]. Stockholm: Fri Tanke.

Applebaum, B. (2003). Social Justice, democratic education and the silencing of words that wound. Journal of Moral Education, 32(2), 151-162.

Arneback, E. (2012). Med kränkningen som mätstock: Om planerande bemötanden av främlingsfientliga uttryck i gymnasieskolan [With 'violations' as the yardstick: Planned responses to expressions of racism in upper secondary school]. PhD dissertation, Örebro University, Sweden.

Arneback, E. (2014). Moral imagination in education: A Deweyan proposal for teachers responding to hate speech. Journal of Moral Education, 43(3), 269-281.

Aven, T. (2012). The risk concept: Historical and recent development trends. Reliability Engineering \& System Safety, 99, 33-44.

Beck, U. (1992). Risk society: Towards a new modernity. London: Sage.

Bergh, A., \& Arneback, E. (2016). Hur villkorar juridifieringen lärarprofessionens arbete med skolans kunskaper och värden? [How does juridification condition the teaching profession's work with educational knowledge and values?]. Utbildning \& Demokrati, 25(1), 11.

Bialostok, S., \& Whitman, R. L. (2012). Education and the risk society: An introduction. In S. Bialostok, W. S. Bradley, \& R. L. Whitman (Eds.), Education and the risk society: Theories, discourse and risk identities in education contexts (pp. 1-34). Rotterdam: Brill.

Biesta, G. (2014). The beautiful risk of education. Boulder: Paradigm Publishers.

Biesta, G. (2016). Good education in an age of measurement: ethics, politics, democracy. London: Routledge.

Boler, M. (2004). All speech is not free: The ethics of 'affirmative action pedagogy'. Counterpoints, 240, 3-13.

Boler, M., \& Zembylas, M. (2003). Discomforting truths: The emotional terrain of understanding difference. In P. P. Trifonas (Ed.), Pedagogies of difference: rethinking education for social change (pp. 116-139). New York: RoutledgeFalmer.

Bornemark, J. (2019). Handlingens paradoxer: En reflektion över tjänstepersoners praktiska kunskap [The paradox of action: A reflection on the practical knowledge of civil servants]. In B. Hellström \& L. Daram (Eds.), Stadsutveckling \& design för motstridiga önskemål: En bok om nödvändigheten av förändring i tanke och handling för sociala bällbarbetsprocesser (pp. 23-37). Stockholm: Arkus.

Bornemark, J. (2020). Horisonten finns alltid kvar: Om det bortglömda omdömet [The horizon is always there: On the forgotten judgement]. Stockholm: Volante.

Callan, E. (2011). When to shut students up: Civility, silencing, and free speech. Theory and Research in Education, 9(1), 3-22. 
Callan, E. (2016). Education in safe and unsafe spaces. Philosophical Inquiry in Education, 24(1), 64-78.

Carlbaum, S. (2017). Complaints, gender and power in governing education. In C. Hudson, M.

Rönnblom, \& K. Teghtsoonian (Eds.), Gender, governance and feminist post-structuralist analysis: Missing in action? (pp. 121-140). London: Routledge.

Cooper, A. (2019). Skolan som demokratiprojekt: En poststrukturell diskursanalys av demokratiuppdrag och lärarsubjekt [School as a democracy project: A poststructural discourse-theoretical analysis of schools' democratic mission and teacher subjects]. PhD dissertation, Karlstad University, Sweden.

Dewey, J. (1922). Human nature and conduct. John Dewey: The middle works, 1899-1924. Vol. 14. Carbondale and Edwardsville: Southern Illinois University Press.

Franck, O. (2020). Ethics education in democratic pluralist contexts. Educational Theory, 70(1), 73-88.

Government Bill 2005/06:38. Trygghet, respekt och ansvar: Om förbud mot diskriminering och annan kränkande behandling av barn och elever [Security, respect and responsibility. The prohibition of discrimination and other degrading treatment of children and students]. Stockholm: Utbildnings- och kulturdepartementet.

Hübinette, T. (2012). Ord som sårar: Om bristen på en interkulturell etik i ett samtida Sverige [Words that wound: On the lack of an intercultural ethic in contemporary Sweden]. In K. GoldsteinKyaga, M. Borgström, \& T. Hübinette (Eds.), Den interkulturella blicken i pedagogik: inte bara goda föresatser (pp. 79-97). Huddinge: Södertörn University.

Hult, A., \& Lindgren, J. (2016). Med lagen som rättesnöre: Kunskapsformer i lärares arbete mot kränkande behandling [Judging by the (law)book: Knowledge forms in teachers' work against degrading behaviour]. Utbildning \& Demokrati, 25(1), 73-93.

Lindgren, J., Carlbaum, S., Hult, A., \& Segerholm, C. (2018). Professional responsibility and accountability?: Balancing institutional logics in the enactment of new regulations and practices against bullying and degrading treatment in Swedish schools. Nordic Studies in Education, 38(4), 368-385.

Martinsson, L., \& Reimers, E. (2014). Inledning [ntroduction]. In L. Martinsson \& E. Reimers (Eds.), Skola i normer (2 ed.) (pp. 9-32). Malmö: Gleerup.

Mouffe, C. (2005). On the political. London: Routledge.

Murphy, M. (2020). Taking education to account? The limits of law in institutional and professional practice. Journal of Education Policy, 1-16.

Novak, J. (2018). Juridification of educational spheres: The case of Swedish school inspection. Uppsala: Acta Universitatis Upsaliensis.

Oxford English Dictionary. (2021). Retrieved 11 March 2021, from www.oed.com.

Renn, O. (1992). Concepts of risk: A classification. In S. Krimsky \& D. Goldning (Eds.), Social theories of risk (pp. 53-79). Westport, Connecticut; London: Praeger.

Rosén, M., Arneback, E., \& Bergh, A. (2020). A conceptual framework for understanding juridification of and in education. Journal of Education Policy, n.d., 1-21.

Ruitenberg, C. (2008). What if democracy really matters. Journal of Educational Controversy, 3(1), 1-8.

Ruitenberg, C. W. (2010). Learning to articulate: From ethical motivation to political demands. In G. Biesta (Ed.), Philosophy of education (pp. 372-380). Urbana: Philosophy of Education Society.

Ruitenberg, C. W. (2017). Location, location, locution: Why it matters where we say what we say. Philosophical Inquiry in Education, 24(3), 211-222.

Runesdotter, C. (2016). Avregleringens pris?: Om juridifieringen av svensk skola ur skolaktörers perspektiv [The price of deregulation?: Juridification in Swedish schools from the perspective of school actors]. Utbildning \& Demokrati, 25(1), 95.

SFS 2008:567. Diskrimineringslag [The discrimination act], SFS 2008:567.

SFS 2010:800. Skollag [The education act], SFS 2010:800. 
Swedish National Agency for Education. (2012). Skolverkets allmänna råd: Arbetet mot diskriminering och kränkande behandling [General guidelines on work against discrimination and degrading treatment]. Stockholm: Skolverket.

Todd, S. (2010). På väg mot ofullkomlighetens pedagogik: Mänskligheten och kosmopolitismen under ompröuning [Toward an imperfect education: facing humanity, rethinking cosmopolitanism] (1st ed.). Stockholm: Liber.

Todd, S., \& Säfström, C. A. (2008). Democracy, education and conflict: Rethinking respect and the place of the ethical. Journal of Educational Controversy, 3(1), Article 12.

Tryggvasson, Á., \& Mårdh, A. (2019). Political emotions in environmental and sustainability education. In K. V. Poeck, L. Östman, \& J. Öhman (Eds.), Sustainable development teaching: Ethical and political challenges (1st ed.) (pp. 234-242.) Abingdon, Oxon;New York, NY; Routledge.

Zembylas, M. (2015). 'Pedagogy of discomfort' and its ethical implications: the tensions of ethical violence in social justice education. Ethics and Education, 10(2), 163-174.

\section{About the Authors}

Maria Rosén is a PhD student in education at Uppsala University. Her research addresses issues of democratic education and juridification of education through the lenses of philosophy of education, education policy, and curriculum theory. Contact: maria.rosen@edu.uu.se

Emma Arneback is an associate professor in education at Örebro University. Her research interests are values and value conflicts in education, focusing primarily on racism and anti-racism. She researches in the fields of philosophy of education, didactics (teaching), and curriculum theory. Contact: emma.arneback@,oru.se 